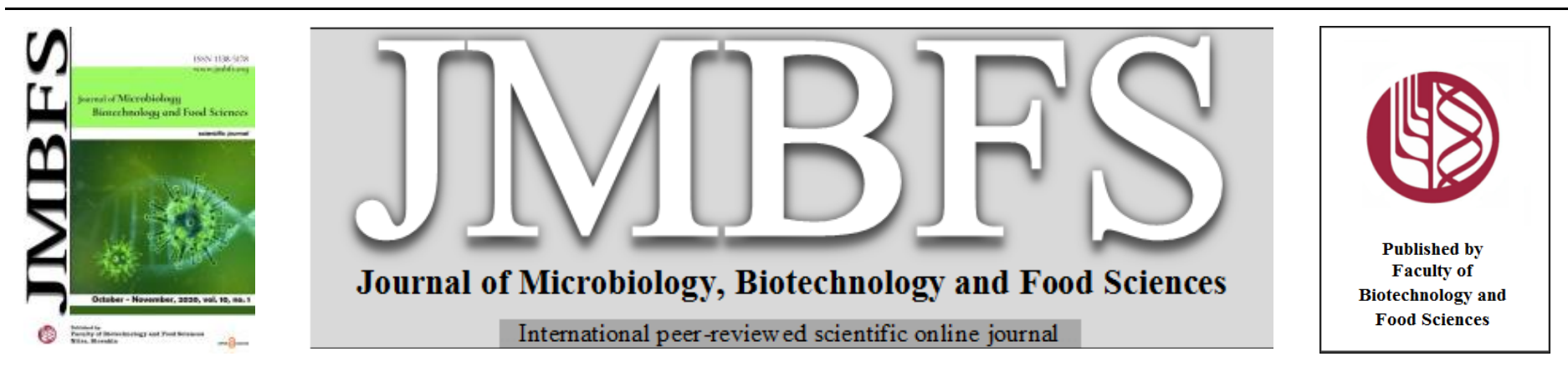

\title{
FOOD PROCESSING AND FERMENTATION STUDIES ON REDUCTION OF PHYTIC ACID IN TRITICUM AESTIVUM AND SORGHUM BICOLOR (L.)
}

\author{
Rashmi Venkatasubbaiah and Sanjay Konasur Rajesh*
}

Address(es):

Department of Biotechnology, JSS Science and Technology University, Sri Jayachamarajendra College of Engineering, Mysore -570006.

*Corresponding author: sanjayrajesh@sjce.ac.in

doi: 10.15414/jmbfs.2020.10.2.166-169

\section{ARTICLE INFO}

Received 20. 6. 2019

Revised 3. 6. 2020

Accepted 3. 6. 2020

Published 1. 10. 2020

Regular article

OPEN $\partial_{\text {AcCESS }}$

\begin{abstract}
Wheat and sorghum are the main dieter cereals for millions of people in Africa and Asia. Their nutritive value in wheat and sorghum is limited due to presence of several anti-nutritional substances such as tannins, phytic acid, proteinase inhibitors and cyanogenic glycosides. Phytic acid (PA) or myo-inositol hexakisphosphate (IP6) in salt form known as phytate is the principal storage form of phosphorus in plant tissues, typically accounting for $60-90 \%$ of total seed phosphorous. Phytase enzyme catalyses the hydrolysis of phytate and releases the phosphate for absorption. This study explains the use of different methods for the reduction of PA content in wheat and sorghum such as soaking, cooking, roasting and fermentation using lactic acid bacteria (LAB). Among all the methods, fermentation using $\mathrm{LAB}$ was found to be effective in reduction of PA. LAB was isolated from the curd sample and fermentation of wheat and sorghum flour was carried out to reduce the PA content. The effect of different fermentation conditions such as $\mathrm{pH}$, temperature and incubation time was also carried out. The results have shown that the optimal fermentation conditions for reduction of PA in wheat and sorghum flour using LAB were; $\mathrm{pH}-6$ (wheat) and 6.5 (sorghum), temperature $32{ }^{\circ} \mathrm{C}$ (wheat) and $37^{\circ} \mathrm{C}$ (sorghum) and fermentation time of 4 to $6 \mathrm{~h}$ for both wheat and sorghum. The percentage of reduction of PA using fermentation process was compared with the other methods such as soaking, cooking and roasting process.
\end{abstract}

Keywords: Phytic acid, Antinutrients, Fermentation, Lactic Acid Bacteria, Wheat, Sorghum

\section{INTRODUCTION}

In contrast to severe malnutrition, from the past 20 years World Health Organization and Research programs were focused on the management of nutritional properties of food with different food processing methods (Konietzny \& Greiner, 2004). Malnutrition in poor communities is not only because of insufficient amount of food but also because of poor nutritional quality of the available food (Brown, 2008). Insufficient and poor quality food intake is also adverse effect on adult health and responsible for many diseases like Anaemia, osteoporosis, rickets and immune diseases due to lack of availability of minerals (Stein, 2010). Micro-nutrients such as Phosphorus, Iron, Calcium and Zinc are essential for all organisms and ideal to act as a catalytic molecule in numerous biochemical reactions (Dangour et al., 2017; Minihane \& Rimbach, 2002). Plant based food products such as wheat (Triticum aestivum) and sorghum (Sorghum bicolor (L.) Moench) are the main cereal crops used for human consumption and they are world's most important crop in terms of production and consumption (Dykes \& Rooney, 2006). They constitute an important dietary source of fibers, complex carbohydrates, proteins, vitamins, and minerals. But their nutritive value is limited due to the presence of several anti-nutritional substances such as phytate, proteinase inhibitors, cyanogenic glycosides and tannins (O'Callaghan et al., 2019; Soetan et al., 2010).

PA has a strong ability to chelate multivalent metal ions, especially $\mathrm{Zn}^{2+}, \mathrm{Mg}^{2+}$ $\mathrm{Ca}^{2+}$ and $\mathrm{Fe}^{2+}$ to form phytate-mineral complexes which are insoluble and therefore unavailable for absorption in the intestinal tract (Coulibaly $\boldsymbol{e t}$ al., 2011;Lopez et al., 1983; Palacios et al., 2008). Its negative charge makes it to bind with positively charged minerals leads to unavailability of minerals for biological activities. Monogastric animals like poultry, swine and human beings do not contain mechanism to hydrolyse PA (Hajati \& Rezaei, 2010) because they have very low or zero phytase activity in their gastrointestinal tracts (Kumar et al., 2010). Hence processed food is required for complete bioaccessible of minerals with lower level of phytic acid. Phytase (myo-inositol hexakis phosphate phophohydrolase) a specific group of phosphatise enzyme, hydrolyses phytic acid to myo-inositol and phosphoric acid. The Phytase enzyme is widely distributed in microorganisms, plants and animals. Among microorganisms Lactic acid bacteria were found to have more phytase activity (Leroy \& De Vuyst, 2004; Palacios et al., 2008; Tamang et al., 2009).

Traditional processes such as soaking, germination and fermentation can activate native grain phytases which degrade inositol-6-phosphate to its lower forms (Liu et al., 2019). On the other hand fermentation is more effective since the organic acids produced by the micro-organisms reduce the $\mathrm{pH}$ of the aqueous cereal mixture close to the optimum $\mathrm{pH}$ required for phytase activity. Phytate degradation can be extensive or complete in products such as lactobacillifermented sorghum (Kumar $\boldsymbol{e t}$ al., 2010). The industrially processed; fermented and enzymatically treated foods are in practice but these are expensive to meet the needs of poor communities (Lai et al., 2013; Leroy \& De Vuyst, 2004). Probiotics are live microbial feed supplements which beneficially affect the host by improving its intestinal microbial balance. Probiotic supplementation to wheat and sorghum has a promising role to play in the bioavailability of essential nutrients (Ajao et al., 2018). Fermentation of wheat and sorghum with LAB reduces the PA content and helps in improved availability of nutritional factors by degrading the IP6 (Grajek et al., 2005). This study reports the use of traditional process and fermentation on reduction of phytic acid in wheat and sorghum flours to enhance the bioavailability of micronutrients in plant based diets.

\section{MATERIAL AND METHODS}

\section{Isolation and identification of Lactic Acid Bacteria (LAB)}

The samples of fresh curd were collected from commercial market. The De Man Rogasa and Sharpe (MRS) broth medium (Hi-media, India) was prepared according to the manufactures instruction. The test tubes containing media were sterilized by autoclaving at $121^{\circ} \mathrm{C}$ with 15 Pounds/ $/ \mathrm{Inch}^{2}$ pressure. $1 \mathrm{~mL}$ of $1: 10$ diluted curd sample prepared was inoculated and incubated at $37{ }^{\circ} \mathrm{C}$ for 24 hours The sterilized MRS agar medium $(15 \mathrm{ml})$ was dispensed into sterile petri plates and a loop full of inoculums from enriched MRS broth was streaked on MRS Agar plates. Plates were incubated for $24 \mathrm{~h}$ at $37{ }^{\circ} \mathrm{C}$ and examined for development of bacterial colonies. The isolated LAB was identified based on 
their morphological and biochemical characteristics such as Gram Staining, Methyl Red Test, Catalase test and Sugar fermentation test.

\section{Phytate degradation during food processing}

Soaking: The seeds of wheat and sorghum were taken separately and were surface sterilized by treating with $0.1 \%$ mercuric chloride and were rinsed and soaked in distilled water $(1: 10 ; \mathrm{w} / \mathrm{v})$ at different time intervals of $1,5,7,10$ and 15 hours at room temperature $\left(28 \pm 2{ }^{\circ} \mathrm{C}\right)$. The soaked seeds were rinsed with distilled water, dried and ground powder was used for PA determination.

Cooking: The flours of wheat and sorghum samples were taken separately mixed with distilled water $(1: 20 \mathrm{w} / \mathrm{v})$ and cooked with continuous stirring at different time intervals of $10,15,30$, and $60 \mathrm{~min}$. The cooked samples were centrifuged and the supernatant was taken for PA estimation.

Roasting: The flours of wheat and sorghum samples were roasted separately at different time intervals of 1, 2, 3, 4, 5 min. The roasted samples were taken for $\mathrm{PA}$ estimation using Modified WADE reagent method.

\section{Fermentation optimization studies}

\section{Preparation of Inoculum}

$10 \mathrm{~mL}$ of MRS broth was prepared in 8 test tubes and autoclaved at $121^{\circ} \mathrm{C}$ for 15 min and cooled at room temperature. A loop full of LAB from slant was inoculated to the above test tubes and incubated at $37^{\circ} \mathrm{C}$ for $24 \mathrm{~h}$ in a shaker incubator at $220 \mathrm{rpm}$.

\section{Fermentation optimization study of pH}

Ten grams of ground samples of sorghum and wheat were separately autoclaved at $121^{\circ} \mathrm{C}$ for $20 \mathrm{~min}$ the samples were mixed uniformly with $100 \mathrm{~mL}$ of sterile distilled water in different conical flasks in an aseptic condition. The $\mathrm{pH}$ of the medium was adjusted to $3,4,5.5,6,6.5,7.4$ and 9 using $0.1 \mathrm{~N} \mathrm{HCl}$ and $\mathrm{NaOH} .10$ $\mathrm{mL}$ of the inoculum was added to the medium. Fermentation was carried out in an incubator shaker at $220 \mathrm{rpm}$ at optimum temperature $37^{\circ} \mathrm{C}$. Aliquots of the fermenting slurries were drawn at 24,48 and $72 \mathrm{~h}$ intervals under aseptic conditions and analyzed for phytic acid using colorimetric WADE reagen method.

\section{Fermentation optimization study of Temperature}

$10 \mathrm{~g}$ of ground samples of sorghum and Wheat were autoclaved separately at $121^{\circ} \mathrm{C}$ for $20 \mathrm{~min}$. Samples were mixed uniformly with $100 \mathrm{~mL}$ of sterile distilled water in different conical flasks in an aseptic condition. $10 \mathrm{~mL}$ of the inoculum was added to the medium. Fermentation was carried out in an incubator shaker at $220 \mathrm{rpm}$ at different temperature 27,32 and $37^{\circ} \mathrm{C}$. Aliquots of the fermenting slurries were drawn at 24,48 and $72 \mathrm{~h}$. Intervals of time under aseptic conditions analyzed for phytic acid using colorimetric WADE reagent method.

\section{Fermentation time optimization study}

Powdered samples of wheat and sorghum were autoclaved at $121^{\circ} \mathrm{C}$ for $20 \mathrm{~min}$. $10 \mathrm{~g}$ of Samples were mixed uniformly with $100 \mathrm{~mL}$ of sterile distilled water in different conical flasks in an aseptic condition. The $\mathrm{pH}$ of the medium was adjusted to 6.5 using $0.1 \mathrm{~N} \mathrm{HCl}$ and $\mathrm{NaOH} .10 \mathrm{~mL}$ of the inoculum was added to the medium. Fermentation of wheat and sorghum sample was carried out in an incubator shaker at $220 \mathrm{rpm}$ at optimum temperatures of $32^{\circ} \mathrm{C}$ (wheat) and $37^{\circ} \mathrm{C}$ (sorghum). Aliquots of the fermenting slurries were drawn at 1, 2, 3, 4, 5, 6, 24, 48 and $72 \mathrm{~h}$ intervals under aseptic conditions. Analysis of phytic acid in samples was carried out using colorimetric WADE reagent method.

\section{Determination of PA content in raw and fermented samples}

The standard graph of sodium phytate was prepared as described in previous reports (Newsome, 1980) and the determination of phytic acid in the raw samples of wheat and Sorghum flour were carried out according to Kwanyuen $\boldsymbol{e t}$ al. (2007). The Fermented samples drawn at different interval of time were centrifuged at $4800 \mathrm{rpm}$ for $20 \mathrm{~min}$ at $10^{\circ} \mathrm{C}$. $1 \mathrm{~mL}$ of supernatant was pipetted out into two test tubes with $2 \mathrm{~mL}$ of distilled water. Each tube was added with $1 \mathrm{~mL}$ of the Wade reagent $\left(0.03 \% \mathrm{FeCl}_{3}-6 \mathrm{H}_{2} \mathrm{O}\right.$ and $0.3 \%$ sulfosalicylic acid in distilled water), and the solution was mixed on a vortex mixer for 5 second. The mixture was centrifuged for $10 \mathrm{~min}$ and the absorbance of supernatant was measured at $490 \mathrm{~nm}$ using colorimeter.

\section{Statistical analysis}

All data were analyzed by one-way analysis of variance (ANOVA) using Microsoft Excel (2010). The values are represented as mean \pm standard deviation (SD). Probability levels ( $\mathrm{P}$ values) $<0.05$ were considered significant.

\section{RESULTS AND DISCUSSION}

\section{Isolation and identification of LAB}

Lactic acid bacteria are commonly found in fermented dairy products Lactobacillus is a genus of lactic acid bacteria and described as a heterogeneous group of regular, non-spore forming, gram-positive, rod shaped non-motile bacteria with catalase negative activity. After the incubation for $24 \mathrm{~h}$, colour of the colonies was found to be creamy to white on the surface of MRS agar plate as shown in the figure 1A. The morphological characteristics were further resolved on the basis of microscopic examination. LAB being gram positive bacteria appears deep purple indicating that they have thick outer layer peptidoglycan. Gram's staining of the bacterial culture showed that they were gram positive, rod shaped and some of them were coccid shaped (Figure 1A-1D). The results of catalase test showed that the isolates were not able to produce air bubbles when mixed with $3 \% \mathrm{H}_{2} \mathrm{O}_{2}$ which confirms that isolates were catalase negative and belong to LAB. The results of sugar fermentation showed that isolates fermented glucose to acid which was evident by changing color of medium from red to yellow. It also showed that LAB was homo fermentative because in case of homo fermentation, there will be production of acid along with the change in color of the medium from red to yellow. Whereas in hetero fermentation, there will be gas production in Durham tube alongside the change in the color. The results of Methyl red test showed that isolates were mixed acid fermenting bacteria that yield a stable acid end product which was evident by changing color of the medium from yellow to red. Similar results were obtained by (Kale, 2014).
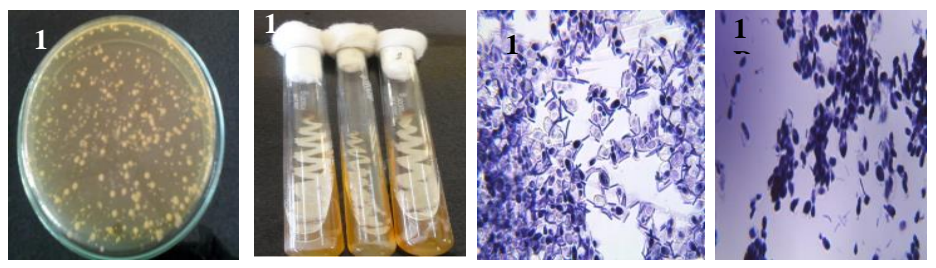

Figure 1 Isolation and identification of Lactic acid bacteria: 1A) Morphology of LAB; 1B) Pure Culture of LAB; 1C) \& 1D) Gram Staining for LAB; 1E) Catalase test; 1F) Sugar fermentation test

\section{Study on effect of food processing methods on Phytic acid degradation}

The estimation of PA was found to be $1.5 \%$ in whole wheat, $2 \%$ in wheat bran, $1.3 \%$ in Fine wheat and $2.1 \%$ in sorghum (Table 1). The estimation was carried out using sodium phytate as a standard (figure 2). There are different methods for PA degradation such as soaking, cooking, roasting and fermentation (Kumar $\boldsymbol{e t}$ al., 2010). Soaking of legume grains and cereal seeds are done as a pre-treatment to facilitate processing, which lasts for 15-20 min, or even longer, depending on further, processing steps. Generally, cereals and legumes are soaked in water overnight; phytate is water-soluble, so a considerable amount of phytate is removed to the water. In addition, this process also enhances the action of naturally occurring phytase in cereals and legumes. It has been shown that phytate hydrolysis, during soaking, is greatly influenced by temperature and $\mathrm{pH}$ (Greiner \& Konietzny, 1999). In the present study reduction of PA in soaked samples was found to be $45 \%$ in whole wheat and $27.5 \%$ in sorghum after soaking for $15 \mathrm{~min}$. Reduction of PA content in cooked samples was found to be $53 \%$ in whole wheat, and $47 \%$ in sorghum at 60 min of cooking. PA reduction in roasted samples was found to be $26 \%$ in whole wheat, and $18.57 \%$ in sorghum at $5 \mathrm{~min}$ of roasting. From the figure 3 it is evident that as the time of soaking, cooking or roasting increases the reduction in PA increased. Phytate, being a heat stable component in plant foodstuffs, is not easily degraded while cooking. However, the intrinsic plant phytase is thermo labile; prolonged exposure to high temperature may lead to the inactivation of endogenous enzyme. Therefore, to improve phytate dephosphorylation during cooking, plants with heat-stable Phytases or addition of exogenous heat-stable Phytases have been recommended (Hotz \& Gibson, 2007).

Table 1 PA content in raw samples

\begin{tabular}{ll} 
Raw Samples & $\%$ Weight $(\mathrm{w} / \mathrm{w})$ \\
Wheat Bran & 2 \\
Fine Wheat & 1.3 \\
Whole Wheat & 1.5 \\
sorghum & 2.1 \\
\hline
\end{tabular}




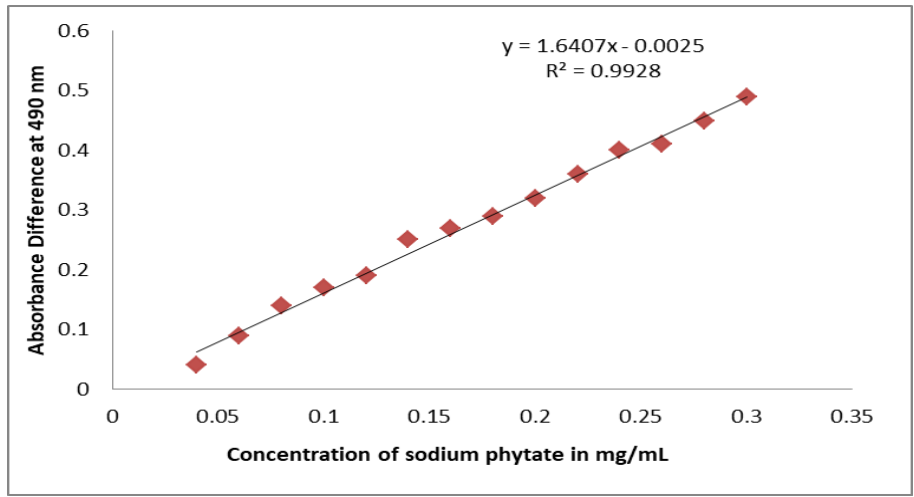

Figure 2 Standard graph of sodium phytate assay
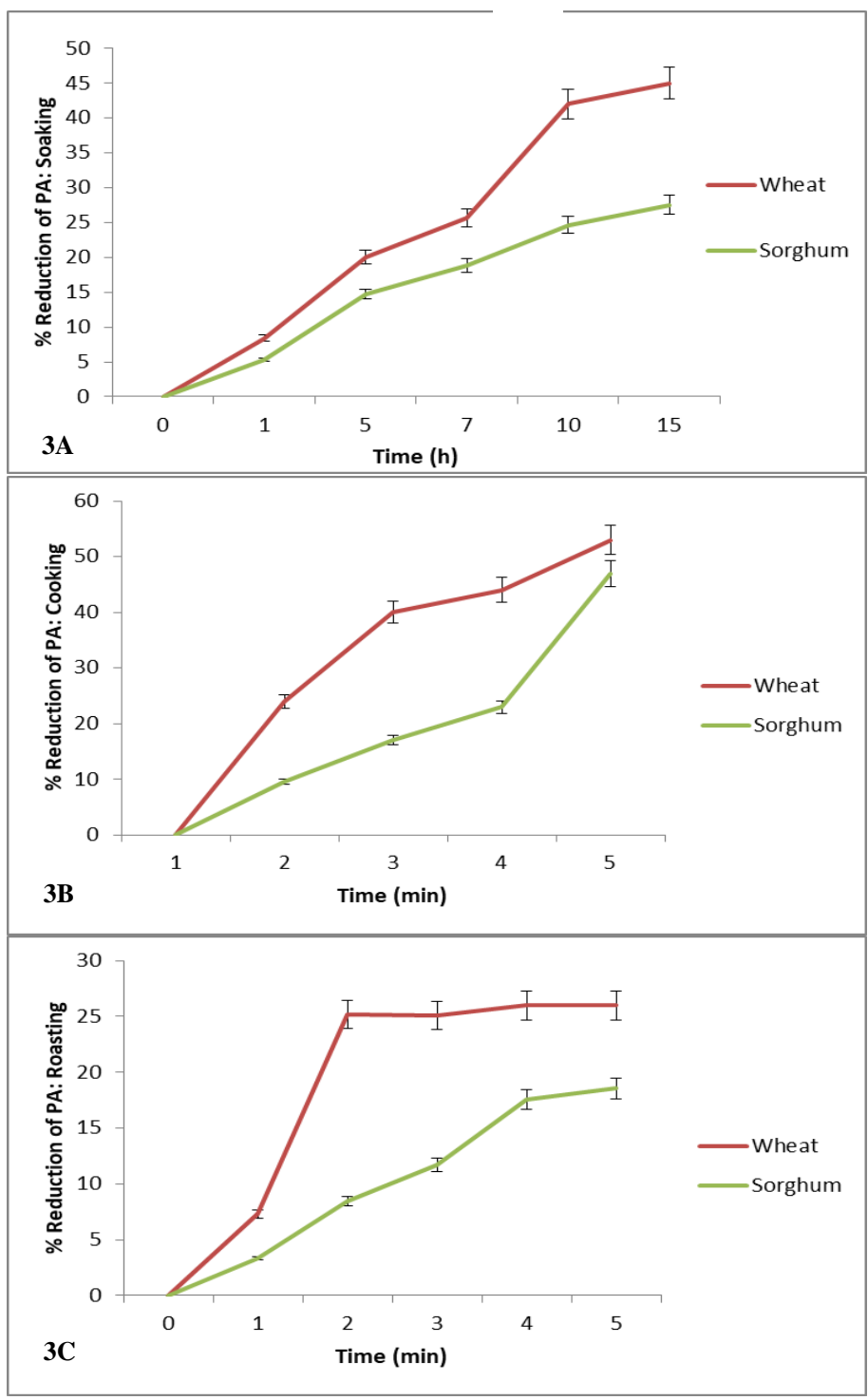

Figure 3 Phytic acid reduction during food processing: 3A) effect of soaking on PA content of wheat \& sorghum; 3B) effect of cooking on PA content of wheat \& Sorghum; 3C) effect of roasting on PA content of wheat \& Sorghum

\section{Study on fermentation optimization for reduction of PA}

LAB from milk and curd were considered to be the possible source of phytase in fermentation. Phytase is also present in wheat and sorghum. As the fermentation continues, it resulted in increased acidity of wheat sample; this activates the phytase enzyme in wheat and sorghum samples (Elyas et al., 2002). The scientific data are interpreted as supporting the hypothesis that either lactic acid bacterial phytase is significantly involved in phytate degradation during sourdough fermentation (Eale, Onietzny et al., 2007; Lopez et al., 2000; Rezaei et al., 2019) or the intrinsic cereal phytases are responsible for phytate degradation after being activated by a fall in $\mathrm{pH}$ due to lactic acid production by the lactic acid (Gupta et al., 2013).
In wheat, it was found that $100 \%$ reduction of $\mathrm{PA}$ occurred in $\mathrm{pH} 6$, temperature $32{ }^{\circ} \mathrm{C} \&$ time 4 to $6 \mathrm{~h}$ of fermentation and there was a change in $\mathrm{pH}$ from 6 changed to 3.96 at $6 \mathrm{~h}$ of fermentation. In sorghum, it was found that $100 \%$ reduction of PA occurred in $\mathrm{pH}-6.5$ temperature $37^{\circ} \mathrm{C} \&$ fermentation time of 4 to $6 \mathrm{~h}$. With prolong of fermentation time the PA content increases due to inhibition of phytase enzyme by phosphates enzyme released from lactic acid bacteria. During fermentation, constant agitation also plays an important role on reduction of PA. After $24 \mathrm{~h}$ of fermentation, PA content remains almost constant (Figure 4-5).

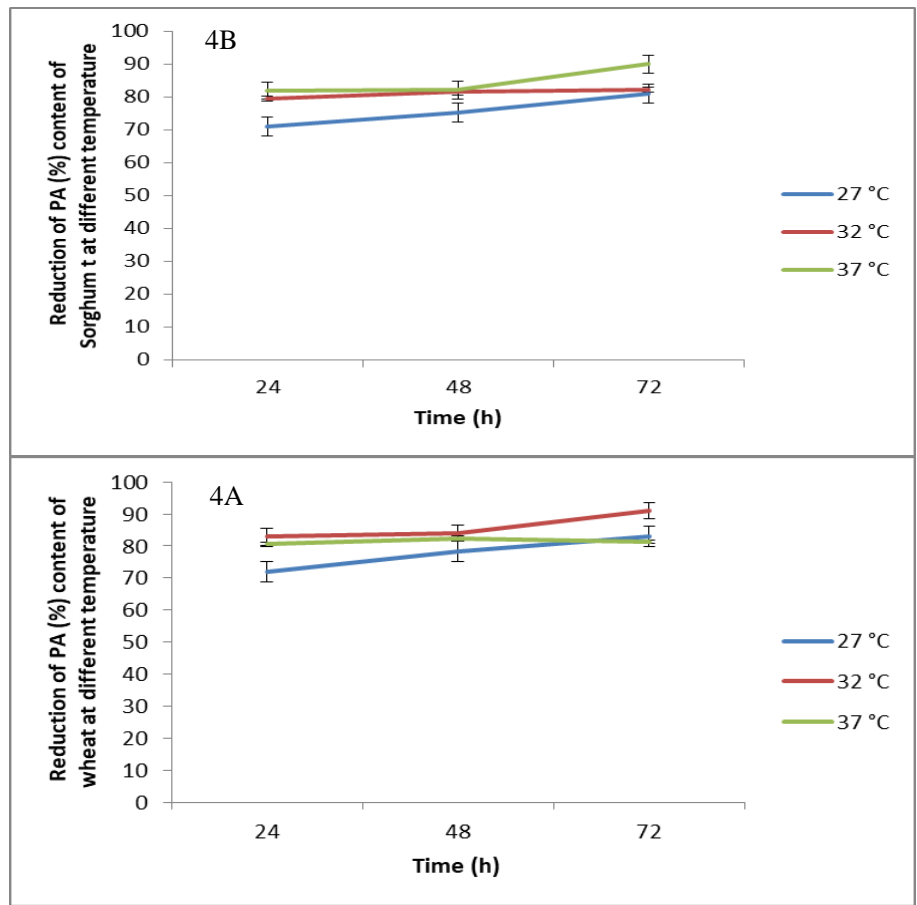

Figure 4 Reduction of PA (\%) after 24, 48 and $72 \mathrm{~h}$ of fermentation at different temperature in wheat (Fig 4A) \& sorghum (Fig 4B).
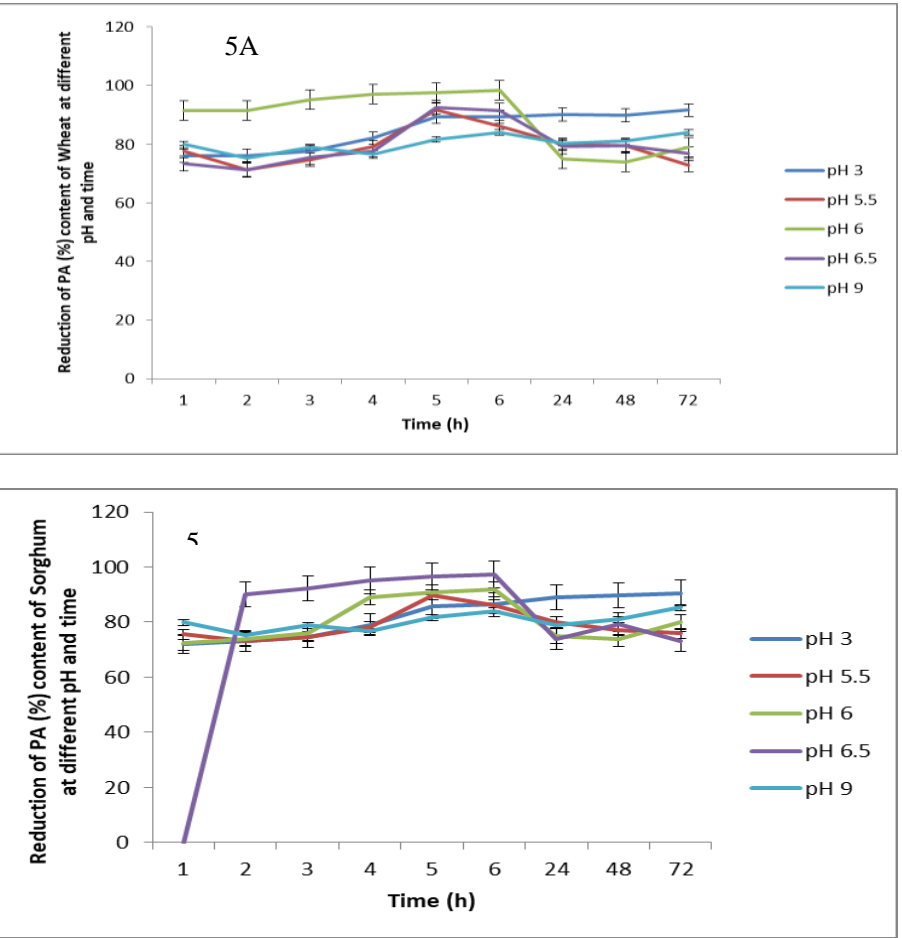

Figure 5 Optimization of $\mathrm{pH}$ and fermentation time on reduction of $\mathrm{PA}$ in whea (fig 5A) \& sorghum (fig 5B)

PA is present in wheat and sorghum is suspected of impairing mineral absorption of $\mathrm{Zn}, \mathrm{Fe}$ and $\mathrm{Ca}$ (Dykes \& Rooney, 2006). The binding of PA alters the solubility, functionality, digestibility and absorption of the food components. PA binds with proteins and mineral nutrient, thereby reducing their bioavailability. The release of phosphate from phytate is initiated by a class of enzymes called phytases which hydrolyse phosphate motilities from PA to release myo inositol 
and inorganic phosphate thereby resulting in the loss of ability of PA to chelate metal ions. LAB Phytase enhance the availability of phosphate from phytate and they also have the potential to be used as a probiotics (Fischer et al., 2014; Greiner \& Konietzny, 1999; H. W. Lopez et al., 2001). Probiotic supplementation to wheat and sorghum has a promising role to play in to increase the bioavailability of essential nutrients (Grajek et al., 2005). Even though there are different methods for degradation of PA in wheat and sorghum such as soaking, cooking and roasting the fermentation process provides optimum conditions for enzymatic degradation of PA present in complex form with polyvalent cations like $\mathrm{Fe}, \mathrm{Zn}, \mathrm{Ca}, \mathrm{Mg}$ and proteins (Minihane \& Rimbach, 2002). The lactic acid fermentation showed greater significance in reduction of PA content when compared to soaking, cooking and roasting. In this study a modified colorimetric WADE reagent method was used for the identification of PA content in raw wheat and sorghum and WADE colorimetric method was used for PA content estimation in fermented samples (H. W. Lopez et al., 2001). The determination of PA content with these colorimetric methods is based on decolouration of the pink $\mathrm{Fe}^{+}$- sulfosalicylate complex (WADE reagent) Increase in absorbance reading $(490 \mathrm{~nm})$ after fermentation showed that reduction of PA content of wheat and sorghum.

\section{CONCLUSION}

In the present study describes the isolation of phytate degrading LAB and optimization of fermentation conditions for degradation of phytate in wheat and sorghum flour. Further, this study can be extended for isolation of other probiotic bacteria such as bifidobacterium for the reduction of PA content in wheat and sorghum. This will help in formulations of LAB with varieties of plant based foods to decrease the phytic acid content and to increase availability of phosphorus.

Acknowledgements: Authors are thankful to Sri Jayachamarajendra College of Engineering, Mysuru for providing the all facility to conduct research.

\section{REFERENCES}

Ajao, O., Banwo, K., Ogunremi, O., \& Sanni, A. (2018). Antimicrobial Properties and Probiotic Potentials of Lactic Acid Bacteria Isolated From Raw Beef in Ibadan, Nigeria. Journal of Microbiology, Biotechnology and Food Sciences, 8(2), 770-773. https://doi.org/10.15414/jmbfs.2018.8.2.770-773.

BROWN, K. H. (2008). Appropriate Diets for the Rehabilitation of Malnourished Children in the Community Setting. Acta Paediatrica, 80(s374), 151-159. https://doi.org/10.1111/j.1651-2227.1991.tb12018.x.

Coulibaly Abdoulaye, Kouakou Brau, C. J. (2011). Phytic Acid in Cereal Grains: Structure, Healthy or Harmful Ways to Reduce Phytic Acid in Cereal Grains and Their Effects on Nutritional Quality. American Journal of Plant Nutrition and Fertilization Technology, 1(1), 1-22. https://doi.org/10.3923/ajpnft.2011.1.22. Dangour, A. D., Mace, G., \& Shankar, B. (2017). Food systems, nutrition, health and the environment. The Lancet Planetary Health, 1(1), e8-e9. https://doi.org/10.1016/s2542-5196(17)30004-9.

Dykes, L., \& Rooney, L. W. (2006). Sorghum and millet phenols and antioxidants. Journal of Cereal Science, 44(3), 236-251. https://doi.org/10.1016/j.jcs.2006.06.007.

Reale, A., Konietzny, U., Coppola, R., Sorrentino, E., \& Greiner, R. (2007). The importance of lactic acid bacteria for phytate degradation during cereal dough fermentation. Journal of agricultural and food chemistry, 55(8), 2993-2997. https://doi.org/10.1021/jf063507n.

Elyas, S. H., El Tinay, A. H., Yousif, N. E., \& Elsheikh, E. A. (2002). Effect of natural fermentation on nutritive value and in vitro protein digestibility of pearl millet. Food chemistry, 78(1), 75-79 https://doi.org/10.1016/S0308 8146(01)00386-7.

Fischer, M. M., Egli, I. M., Aeberli, I., Hurrell, R. F., \& Meile, L. (2014). Phytic acid degrading lactic acid bacteria in tef-injera fermentation. International Journal of Food Microbiology, 190, 54-60. https://doi.org/10.1016/j.ijfoodmicro.2014.08.018.

Grajek, W., Olejnik, A., \& Sip, A. (2005). Probiotics, prebiotics and antioxidants as functional foods. Acta biochimica polonica-english edition-, 52(3), 665. https://doi.org/10.1038/sj.bmt.1705084.

GREINER, R., \& KONIETZNY, U. (1999). Improving enzymatic reduction of myo-inositol phosphates with inhibitory effects on mineral absorption in black beans (Phaseolus vulgaris var. preto). Journal of food processing and preservation, 23(3), 249-261 https://doi.org/10.1111/j.17454549.1999.tb00383.x.

Gupta, R. K., Gangoliya, S. S., \& Singh, N. K. (2013). Reduction of phytic acid and enhancement of bioavailable micronutrients in food grains. Journal of Food Science and Technology, 52(2), 676-684. https://doi.org/10.1007/s13197-0130978-y

Hajati, H., \& Rezaei, M. (2010). The application of prebiotics in poultry production. International Journal of Poultry Science, 9(3), 298-304. https://doi.org/10.3923/ijps.2010.298.304.
Hotz, C., \& Gibson, R. S. (2007). Traditional Food-Processing and Preparation Practices to Enhance the Bioavailability of Micronutrients in Plant-Based Diets The Journal of Nutrition, 137(4), 1097-1100. https://doi.org/10.1093/jn/137.4.1097.

Kale, P. S. (2014). Isolation and identification of bacteria from curd and its application in probiotic chocolate. Pelagia Research Library European Journal of Experimental Biology, 4(6), 95-97. Retrieved from www.pelagiaresearchlibrary.com.

Konietzny, U., \& Greiner, R. (2004). Bacterial phytase: Potential application, in vivo function and regulation of its synthesis. Brazilian Journal of Microbiology, 35(1-2), 11-18. http://dx.doi.org/10.1590/S1517-83822004000100002.

Kumar, V., Sinha, A. K., Makkar, H. P. S., \& Becker, K. (2010). Dietary roles of phytate and phytase in human nutrition : A review. Food Chemistry, 120(4), 945959. https://doi.org/10.1016/j.foodchem.2009.11.052.

Gao, Y., Shang, C., Maroof, M. A., Biyashev, R. M., Grabau, E. A., Kwanyuen, P., ... \& Buss, G. R. (2007). A modified colorimetric method for phytic acid analysis in soybean. Crop Science, 47(5), 1797-1803. https://doi.org/10.2135/cropsci2007.03.0122.

Lai, L. R., Hsieh, S. C., Huang, H. Y., \& Chou, C. C. (2013). Effect of lactic fermentation on the total phenolic, saponin and phytic acid contents as well as anti-colon cancer cell proliferation activity of soymilk. Journal of Bioscience and Bioengineering, 115(5), 552-556. https://doi.org/10.1016/j.jbiosc.2012.11.022.

Leroy, F., \& De Vuyst, L. (2004). Lactic acid bacteria as functional starter cultures for the food fermentation industry. Trends in Food Science and Technology, 15(2), 67-78. https://doi.org/10.1016/j.tifs.2003.09.004.

Liu, K., Zheng, J., Wang, X., \& Chen, F. (2019). Effects of household cooking processes on mineral, vitamin $\mathrm{B}$, and phytic acid contents and mineral bioaccessibility in rice. Food Chemistry, 280, 59-64. https://doi.org/10.1016/j.foodchem.2018.12.053.

Lopez, H. W., Krespine, V., Guy, G., Messager, A., Demigne, C., \& Remesy, C. (2001). Prolonged fermentation of whole wheat sourdough reduces phytate level and increases soluble magnesium. Journal of Agricultural and Food Chemistry, 49(5), 2657-2662. https://doi.org/10.1021/jf001255z.

Lopez, H. W., Ouvry, A., Bervas, E., Guy, C., Messager, A., Demigne, C., \& Remesy, C. (2000). Strains of lactic acid bacteria isolated from sour doughs degrade phytic acid and improve calcium and magnesium solubility from whole wheat flour. Journal of Agricultural and Food Chemistry, 48(6), 2281-2285. https://doi.org/10.1021/jf000061g.

LOPEZ, Y., GORDON, D. T., \& FIELDS, M. L. (1983). Release of Phosphorus from Phytate by Natural Lactic Acid Fermentation. Journal of Food Science, 48(3), 953-954. https://doi.org/10.1111/j.1365-2621.1983.tb14938.x.

Marie Minihane, A., \& Rimbach, G. (2002). Iron absorption and the iron binding and anti-oxidant properties of phytic acid. International journal of food science \& technology, 37(7), 741-748. https://doi.org/10.1046/j.1365-2621.2002.00619.x.

Latta, M., \& Eskin, M. (1980). A simple and rapid colorimetric method for phytate determination. Journal of Agricultural and Food Chemistry, 28(6), 1313 1315. https://doi.org/10.1021/if60232a049.

O’Callaghan, Y. C., Shevade, A. V., Guinee, T. P., O’Connor, T. P., \& O’Brien, N. M. (2019). Comparison of the nutritional composition of experimental fermented milk:wheat bulgur blends and commercially available kishk and tarhana products. Food Chemistry, 278, 110-118 https://doi.org/10.1016/j.foodchem.2018.11.026.

Palacios, M. C., Haros, M., Sanz, Y., \& Rosell, C. M. (2008). Selection of lactic acid bacteria with high phytate degrading activity for application in whole wheat breadmaking. LWT - Food Science and Technology, 41(1), 82-92. https://doi.org/10.1016/j.lwt.2007.02.005.

Rezaei, S., Najafi, M. A., \& Haddadi, T. (2019). Effect of fermentation process, wheat bran size and replacement level on some characteristics of wheat bran, dough, and high-fiber Tafton bread. Journal of Cereal Science, 85(October 2017), 56-61. https://doi.org/10.1016/j.jcs.2018.11.019.

Soetan, K. O., Olaiya, C. O., \& Oyewole, O. E. (2010). The importance of mineral elements for humans, domestic animals and plants. African Journal of Food Science, 4(5), 200-222. https://doi.org/10.1186/s12302-017-0116-y.

Stein, A. J. (2010). Global impacts of human mineral malnutrition. Plant and Soil, 335(1), 133-154. https://doi.org/10.1007/s11104-009-0228-2.

Tamang, J. P., Tamang, B., Schillinger, U., Guigas, C., \& Holzapfel, W. H. (2009). Functional properties of lactic acid bacteria isolated from ethnic fermented vegetables of the Himalayas. International Journal of Food Microbiology, 135(1), 28-33. https://doi.org/10.1016/j.ijfoodmicro.2009.07.016. 